\title{
NILAI-NILAI MULTIKULTURAL DAN PENDIDIKAN ISLAM DALAM TRADISI TEREMPOH MELAYU SINTANG
}

\author{
Dian Findhiani Eka Hadi Lestari, Hermansyah dan Syamsul Kurniawan \\ IAIN Pontianak, Indonesia \\ Fitridian.395@gmail.com
}

\begin{abstract}
This research is a study of the trempoh tradition that was carried out by the Malay community in sub-district Sintang, Districts Sintang, province West Borneo. The trempoh tradition is a repertoire of local culture that serves as a means of friendship and unifying between tribes, religions and ethnicities living in sub-district Sintang. This research determine to know how the implementation, multicultural values, and Islamic education values from the trempoh tradition. This research is a field research that uses descriptive qualitative method to describe the implementation and values of the tradition that are supplanted through observation, interviews and documents related to the tradition. The results of this study explain that the implementation of the trempoh tradition consists of the takbiran activities, family terempoh, male trempoh, female trempoh, and family terempoh. In the trempoh traditions there are multicultural values, such as: diversity, equality, humanity, justice, and democracy, while the Islamic education values from trempoh traditions, such as: religious, compassion, politeness, and social care.
\end{abstract}

Keywords: Terempoh Tradition, Multicultural Values, Islamic Education Values

\begin{abstract}
Abstrak: Penelitian ini merupakan studi terhadap tradisi terempoh yang dilakukan oleh masyarakat Melayu di Kecamatan Sintang, Kabupaten Sintang, Provinsi Kalimantan Barat. Tradisi terempoh merupakan khasanah budaya lokal yang berfungsi sebagai sarana silaturahmi dan pemersatu antar suku, agama dan etnis yang tinggal di Kecamatan Sintang. Penelitian ini bertujuan untuk mengetahui pelaksanaan, nilai-nilai multikultur, dan nilai-nilai pendidikan Islam dari tradisi terempoh. Penelitian ini merupakan penelitian lapangan yang menggunakan metode deskriptif kualitatif untuk memaparkan pelaksanaan dan nilai-nilai dari tradisi terempoh melalui observasi, wawancara dan dokumen terkait tradisi terempoh. Hasil penelitian ini menjelaskan bahwa pelaksanaan tradisi terempoh terdiri dari kegiatan takbiran keliling, terempoh keluarga, terempoh laki-laki, terempoh perempuan, dan terempoh kaum kerabat. Dalam tradisi terempoh terdapat nilai-nilai multikultural, berupa: keragaman, kesetaraan, kemanusiaan, keadilan, dan demokrasi, sementara nilai-nilai pendidikan Islam dari tradisi terempoh, yaitu: religius, kasih sayang, kesantunan, dan kepedulian sosial.
\end{abstract}

Kata Kunci: Tradisi Terempoh, Nilai-Nilai Multikultural, Pendidikan Islam

\section{A. Pendahuluan}

Manusia pada dasarnya merupakan mahluk sosial yang saling membutuhkan dalam menjalani kehidupannya. Dalam hubungan antar 
manusia tersebut, terbentuk suatu kebiasaan yang dilakukan terus menerus dan disepakati bersama oleh suatu komunitas yang didalamnya terdapat nilai atau norma yang dijaga secara bersama-sama. Kebiasaan ini kemudian menjadi suatu tradisi atau budaya.

Menurut Koentjaraningrat, kebudayaan adalah keseluruhan sistem gagasan, tindakan dan hasil karya manusia dalam rangka kehidupan masyarakat yang dijadikan milik diri manusia dengan belajar ${ }^{42}$. Alo selanjutnya menambahkan, norma budaya umumnya berkaitan dengan standar perilaku yang disepakati demi kepentingan bagaimana setiap orang harus bersikap, dan pada umumnya aturan-aturan itu biasanya tidak tertulis dan kita pelajari secara tidak sadar dan lahir dari kebiasaan dan kebudayaan kita yang pada akhirnya menjadi tradisi yang akan melahirkan nilai-nilai. ${ }^{43}$

Kebudayaan di masyarakat akan turut serta membentuk dan mempengaruhi kepribadian individu seseorang. Kebudayaan memberikan pengalaman nyata dan menjadi guru terbaik dalam pembentukan jati diri manusia sebagaimana ungkapan "pengalaman ialah guru terbaik" menjelaskan bagaimana suatu kebiasaan dapat memberikan kontribusi besar bagi individu atau kelompok. Kebiasaan yang ada di masyarakat ada yang baik dan buruk, ada yang dilestarikan dan ada pula yang diganti atau ditinggalkan. Kebiasaan baik cenderung dijaga sehingga menjadi ciri khas atau kebudayaan suatu komunitas.

Penelitian ini akan meneliti tentang tradisi masyarakat melayu di Kec. Sintang, Kab. Sintang, Kalimantan Barat yakni tradisi terempoh. Tujuan penelitian ini adalah untuk mengetahui tiga hal, yaitu: Pertama, bagaimana pelaksanaan tradisi terempoh; kedua, nilai-nilai multikultur tradisi terempoh; dan ketiga, nilai-nilai pendidikan Islam tradisi terempoh. Kecamatan Sintang memiliki luas wilayah 277,05 $\mathrm{km}^{2}$ atau 1,28\% dari luas wilayah Kabupaten Sintang. Dengan luas tersebut, Kecamatan Sintang merupakan kecamatan

\footnotetext{
42 Koentjaraningrat, Pengantar Ilmu Antropologi, (Jakarta: Aksara Baru, 1985), hlm. 180.

${ }^{43}$ Alo Liliweri, Pengantar Studi Kebudayaan, (Bandung: Nusa Media, 2014), hlm. 93.
} 
dengan luas wilayah terkecil di Kabupaten Sintang. Jumlah penduduk di Kecamatan Sintang mencapai 65.939 jiwa dengan jumlah laki-laki 33.464 jiwa dan perempuan 32.475 jiwa (data tahun 2013) ${ }^{44}$.

Tradisi terempoh adalah salah satu khazanah budaya lokal yang menjadi tradisi turun temurun di masyarakat Melayu Sintang. Tradisi terempoh membentuk pola perilaku dan membingkai pandangan hidup masyarakat Melayu Sintang dan menjadi simbol kerukunan antar suku, umat beragama dan etnis pada masyarakat majemuk di Kabupaten Sintang. Dalam buku Gusti M.F, “Tradisi Terempoh dalam Era Modernisasi” menjelaskan bagaimana prosesi terempoh memiliki tempatnya dalam masyarakat majemuk di Kecamatan Sintang. Buku itu membahas tentang motivasi seseorang mengikuti tradisi terempoh, makna tradisi terempoh, dan nilai yang terkandung dalam tradisi terempoh ${ }^{45}$. Penelitian lain dilakukan oleh Halimatus sa'diyah tahun 2005 tentang “Budaya Terempoh pada Masyarakat RT. 06/ RW. 02 Kelurahan Kapuas Kiri Hulu Sintang dalam Perspektif Pendidikan Islam" yang mengkaji tentang bagaimana pelaksanaan tradisi terempoh dan nilai pendidikan Islam dari tradisi tersebut. Intinya bahwa tradisi terempoh sejalan dengan nilai-nilai pendidikan Islam, yakni Akidah, Akhlak dan Syariah ${ }^{46}$. Pada penelitian ini, tradisi terempoh dipandang dari sudut pandang yang sedikit berbeda, yaitu tentang nilai multikultural dari tradisi trempoh. Pada pelaksanaan tradisi, penelitian berfokus pada bentuk-bentuk trempoh, sedangkan tentang nilai pendidikan Islam mengalami pendalaman dari penelitian terdahulu.

Kata berterempoh atau terempoh diambil dari bahasa Melayu Sintang yang dapat didefinisikan sebagai suatu kegiatan silaturahmi masyarakat Melayu yang dilakukan secara beramai-ramai dengan prosesi naik ke rumah-rumah

${ }^{44}$ Badab Pusat Statistik Kacamatan Sintang, Kecamatan Sintang Dalam Angka 2014, (Sintang: BPS Kec. Sintang, 2014).

${ }^{45}$ Gusti Muhammad Fadli, Tradisi Terempoh dalam Era Modernisasi: Kajian Tradisi Masyarakat Melayu Sintang-Kalimantan Barat, (Sintang: Sultan Nata, 2017).

${ }^{46}$ Halimatussa' diah, "Budaya Terempoh pada Masyarakat Rt. 06/Rw. 02, Kelurahan Kapuas Kiri Hulu, Sintang dalam Perspektif Pendidikan Islam", Skripsi tidak diterbitkan, Pontianak: IAIN Pontianak, 2005. 
masyarakat. Adapun aktifitas atau prosesi naik ke rumah-rumah dalam tradisi terempoh, biasa disebut dengan netai ${ }^{47}$ atau nerempoh ${ }^{48}$. Dalam era modenisasi saat ini, tradisi terempoh memiliki makna tersendiri dalam masyarakat, yaitu: Pertama, sebagai simbol yang dimaknai bersama yang di dalamnya terdapat nilai-nilai religi, yaitu menghormati dan mendoakan orang yang masih hidup juga yang sudah meninggal; Kedua, sebagai media silaturahmi yang di dalamnya terdapat nilai sosial, antara lain: nilai kebersamaan dan silaturahmi antar sesama keluarga kaum kerabat dan sesama muslim; Ketiga, sebagai pelestarian dari budaya dan simbol dari suatu daerah yang di dalamnya terdapat nilai-nilai luhur yang tetap dipertahankan sehingga tetap menjaga eksistensinya ${ }^{49}$.

Sejarah lahirnya tradisi terempoh tidak diketahui secara pasti, namun menurut informasi masyarakat lokal, terempoh telah ditradisikan turun menurun sejak zaman nenek moyang dan sebagian yang lain menyebutkan tradisi ini lahir sejak terjadinya pemekaran wilayah keraton pada tahun 1986. Hingga saat ini, tradisi terempoh yang sudah membudaya itu menjadi kebanggaan masyarakat setempat khususnya dan masyarakat yang merayakan pada umumnya ${ }^{50}$. Nyai Taenah menceritakan bahwa tradisi terempoh telah ada sejak mereka lahir. Mereka mengikuti apa yang orang tua mereka lakukan dan tradisi ini sudah ada dari generasi ke generasi di masyarakat Melayu Sintang. Tradisi ini diduga telah ada sejak jaman nenek moyang, khususnya saat Islam menyebar ke Sintang saat kerajaan Sintang berubah menjadi kesultanan pada masa pemerintahan Sultan Nata ${ }^{51}$.

Jika tradisi terempoh diibaratkan sosok manusia, maka usianya tidak muda lagi. Keunikan dari tradisi terempoh adalah dalam pelaksanaannya

\footnotetext{
${ }^{47}$ Disebut netai, karena masyarakat menaiki semua rumah secara bergiliran dan berurutan dengan melakukan semua prosesi dan terakhir makan-makan hal tersebut dilakukan hingga rumah terakhir.

${ }^{48}$ Nerempoh silaturahmi serentak, atau berkunjung secara beramai-ramai ke rumah-rumah secara bergiliran hingga selesai.

${ }^{49}$ Fadli, Tradisi Terempoh......, hlm. 79.

${ }^{50}$ Halimatussa'diah, “Budaya Terempoh...., hlm. 29.

${ }^{51}$ Hasil wawancara dengan Nyai Taefah pada Agustus 2016.
} 
dapat menerima suku, agama dan etnis lain untuk ikut terlibat dalam trasidi tersebut. Berterempoh dilakukan untuk menyambung tali silaturahmi dan mempertahankan adat istiadat yang dalam prosesinya kental dengan nilai-nilai Islam. Pelaku tradisi ini ialah orang Melayu ${ }^{52}$. Syamsul Kurniawan menjelaskan, apapun etnisnya, ketika ia menganut agama Islam, meskipun ia beretnis Jawa, Sunda, Bugis, Dayak bahkan Tionghoa, ia dapat disebut Melayu ${ }^{53}$.

Dalam tradisi terempoh termuat konsep multikultural yakni aktivitas yang ada didalamnya memiliki dinamika dan pola dari masyarakat melalui tindakan-tindakan sosial dengan proses yang panjang. Karena ruang lingkup dari multikultural selalu berangkat dari kata multi atau banyak, dan yang paling utama dari multikultural ialah kesetaraan perlakuan antara hak tiap suku, agama dan etnis. Untuk menyikapi multi suku, etnik, agama, dan budaya, maka dari itu masing-masing kelompok harus diposisikan sejajar dalam masyarakat agar tidak ada kelompok masyarakat yang merasa lebih dominan, merasa lebih tinggi, dan merasa budayanya lebih baik dari kelompok masyarakat yang lain. Dalam tradisi terempoh juga termuat nilai-nilai pendidikan Islam, karena pada umumnya tradisi terempoh sama dengan halal bi halal54. Sebagai agama paripurna, secara instrinsik Islam memiliki kelenturan dalam berinteraksi dengan realitas kehidupan umat manusia. Kelenturan tidak berarti Islam "membenarkan" apa saja yang menjadi tuntutan realitas kehidupan, tapi mempertimbangkan, mengakomodir, dan mengarahkan tuntutan itu dalam rangka mewujudkan kemaslahatan hidup manusia ${ }^{55}$. Penelitian ini dimaksudkan untuk menggali lebih dalam dan spesifik tentang

\footnotetext{
52 Makna orang "Melayu" di sini tidak mengarah pada satu suku atau etnis tertentu.

53 Syamsul Kurniawan, "Serapah dalam Masyarakat Melayu Kampung Saigon Kota Pontianak", dalam Jurnal Religi, Vol. IX, No. 1, 2013, hlm. 96-119.

54 Menurut KBBI, kata "halal" memiliki dua makna yakni membuka buhul dan mengikhlaskan. Sesuai dengan peribahasa Arab yang derkaitan dengan ini "Hai pembuhul ingatlah "halal". Maksud dari kata pembuhul ialah "buka buhul hatimu, janganlah diikuti perasaan marah itu." Sederhananya ini halal bagimu, artinya sesuatu yang sudah diikhlaskan diridhai, dan dihalalkan jalannya.

55 Mahmud Arif, "Islam, Kearifan Lokal dan Kontekstualisasi Pendidikan: Kelenturan, Signifikansi, dan Implikasi Edukatifnya", dalam Jurnal Al-Tahrir, Vol. 15, No. 1, 2015, hlm. 86.
} 
pelaksanaan dan nilai-nilai yang terkandung dari tradisi terempoh yang dilaksanakan masyarakat Melayu Sintang.

\section{B. Metode Penelitian}

Penelitian ini merupakan penelitian lapangan (field research) dengan pendekatan deskriptif kualitatif untuk memaparkan dan menggambarkan secara menyeluruh tentang tradisi terempoh masyarakat Melayu Sintang, tepat pada masyarakat melayu yang tinggal di kawasan keraton Sintang, Kec. Sintang, Kab. Sintang, Kalimantan Barat. Dalam penelitian, peneliti berperan sebagai pelaku karena hidup dan besar di lingkungan yang menjalani tradisi terempoh dan sekaligus sebagai peneliti yang mencari makna dan nilai dari tradisi yang terus dilestarikan dan turun menurun dari generasi ke generasi dalam masyarakat Melayu Sintang. Sumber data yang digunakan dalam penelitian diperoleh dari sumber data primer dan skunder. Sumber data primer terdiri dari: tokoh agama, sesepuh, dan masyarakat yang ikut tradisi terempoh, sedangkan data skunder diperoleh dari dokumen-dokumen yang relevan untuk menunjang penelitian. Sumber data primer disajikan dalam tabel berikut:

Tabel 1

Sumber Data Primer

\begin{tabular}{|c|c|c|c|}
\hline No & Nama & Fokus Data & Keterangan \\
\hline 1 & Ahmad Bakrie & $\begin{array}{l}\text { Gambaran Umum } \\
\text { Masyarakat Sintang }\end{array}$ & Lurah \\
\hline 2 & Ayah Long & $\begin{array}{c}\text { Sejarah Tradisi } \\
\text { Terempoh }\end{array}$ & Tokoh Agama \\
\hline 3 & $\begin{array}{l}\text { Toni dan } \\
\text { Nurhayati }\end{array}$ & $\begin{array}{c}\text { Pelaksanaan Tradisi } \\
\text { Terempoh }\end{array}$ & $\begin{array}{c}\text { PNS BKD yang } \\
\text { Istrinya Masyarakat } \\
\text { Pendatang }\end{array}$ \\
\hline 4 & Ahmadin & $\begin{array}{c}\text { Pelaksanaan, Urutan dan } \\
\text { Nilai-Nilai Tradisi } \\
\text { Terempoh }\end{array}$ & Tokoh Masyarakat \\
\hline 5 & $\begin{array}{l}\text { Rohayatun, } \\
\text { Yulanda, dan } \\
\text { Sarifudin }\end{array}$ & $\begin{array}{l}\text { Nilai-Nilai Tradisi } \\
\text { Terempoh }\end{array}$ & $\begin{array}{l}\text { Masyarakat } \\
\text { Pendatang }\end{array}$ \\
\hline 6 & Halimatus sa'diyah & $\begin{array}{c}\text { Nilai-Nilai Tradisi } \\
\text { Terempoh }\end{array}$ & $\begin{array}{c}\text { Peneliti Tradisi } \\
\text { Terempoh }\end{array}$ \\
\hline 7 & Sabaruddin dan & Sejarah Tradisi & Pemerhati Seni \\
\hline
\end{tabular}




\begin{tabular}{|c|c|c|c|}
\hline & Syamsul Bachri & Terempoh & \\
\hline 8 & Syafariyah & $\begin{array}{c}\text { Nilai-Nilai Tradisi } \\
\text { Terempoh }\end{array}$ & $\begin{array}{c}\text { Aktifis Sosial dan } \\
\text { Dharma Wanita }\end{array}$ \\
\hline
\end{tabular}

Adapun sumber data sekunder diperoleh dari: 1) Buku yang ditulis oleh Gusti Muhammad Fadli yang berjudul “Tradisi Terempoh dalam Era Modernisasi: Kajian Tradisi Masyarakat Melayu Sintang-Kalimantan Barat" tahun 2017, 2) Skripsi Halimatussa'diah yang berjudul “Budaya Terempoh pada Masyarakat RT. 06/RW. 02, Kelurahan Kapuas Kiri Hulu, Sintang dalam Perspektif Pendidikan Islam" IAIN Pontianak tahun 2005, dan 3) diary book milik peneliti tentang tradisi terempoh. Dalam penelitian ini, teknik pengumpulan data menggunakan teknik observasi partisipatif, wawancara mendalam (in-depth interview), dan dokumentasi. Penelitian dilakukan melalui tiga tahap, yaitu: 1) studi pendahuluan, 2) penyelidikan lapangan, dan 3) penulisan hasil penelitian. Kegiatan studi pendahuluan dilakukan dengan mengumpulkan data tentang gambaran umum Kec. Sintang dan sejarah terempoh masyarakat Melayu Sintang melalui dokumen (sumber data skunder), lalu kegiatan selanjutnya adalah penelitian lapangan yang dilakukan selama rentang waktu \pm satu tahun.

Observasi dilakukan pada hari raya Islam yakni saat Idul Fitri dan Idul Adha di kawasan Keraton Sintang, sementara wawancara dilakukan selama \pm satu minggu dengan mewawancarai sumber data primer. Analisis data penelitian menggunakan teknik analisis data milik Miles dan Hubermen ${ }^{56}$, meliputi: reduksi data; penyajian data; dan penarikan kesimpulan dari datadata yang terkumpul saat penelitian dilakukan. Untuk memperoleh keabsahan data, peneliti menggunakan tiga teknik, yaitu: 1) memperpanjang masa penelitian, 2) trianggulasi data, dan 3) pemeriksaan anggota (member check) ${ }^{57}$ agar data-data yang diperoleh dapat maksimal dan teruji keabsahannya.

\footnotetext{
${ }^{56}$ Metthew B.M. dan A. M. Huberman, Analisis Data Kualitatif: Buku Sumber tentang MetodeMetode Baru, Penerjemah: Tjetjep Rohendi Rohidi, (Jakarta: UI-Press, 2014), hlm. 16-20.

57 Lexy J. Moleong, Metodologi Penelitian Kualitatif, (Bandung: Remaja Rosdakarya, 2007), hlm. 324-327.
} 


\section{Pelaksanaan Tradisi Terempoh}

Tradisi terempoh merupakan kearifan lokal masyarakat Melayu Sintang yang telah ada sejak jaman dahulu. Menurut Ayah Long, Dia telah mengikuti tradisi terempoh sejak tahun 1965 yang pada masa itu, dari rumah besar sampai ke sungai Mawang baru terdapat sekitar 20 rumah $^{58}$. Disebut kearifan lokal karena tradisi ini diakui oleh masyarakat dan terbukti berguna untuk menguatkan kohesi sosial, meneguhkan jati diri, mengurai masalah bersama, dan memajukan budaya adalah wujud kearifan lokal (dalam fikih dikenal dengan al-urf) ${ }^{59}$. Berdasarkan observasi dan analisis di lapangan, maka peneliti membagi tradisi terempoh menjadi 4, yaitu:

\section{Terempoh Malam (Takbiran Keliling)}

Terempoh malam adalah kegiatan takbiran yang dilakukan oleh laki-laki pada malam terakhir puasa atau masyarakat lebih sering menyebutnya dengan takbiran keliling ${ }^{60}$. Prosesi takbiran keliling dilakukan hanya oleh para lelaki dengan cara berkeliling kampung sambil mengumandangkan takbir dan naik ke rumah warga masyarakat, sementara para perempuan menunggu di rumah sambil menyiapkan hidangan untuk menyambut para penerempoh. Tradisi terempoh pada malam Idul Fitri dilakukan sebagai bentuk syukur atas tibanya hari kemenangan umat Islam, yakni setelah melalui puasa bulan Ramadhan yang penuh rahmat, ampunan dan kebaikan. Begitu pula pada malam Idul Adha, kegiatan hanya dilakukan oleh laki-laki saja. Hal ini mengingat waktu yang singkat karena keesokan harinya, akan dilakukan penyembelihan hewan kurban. Perbedaaan antara terempoh dengan terempoh malam yaitu terempoh malam atau takbiran keliling hanya dilakukan pada malam Idul Fitri dan malam Idul Adha, sedangkan terempoh dapat dilakukan pada siang hingga malam hari selain dua malam hari raya tersebut.

58 Wawancara dengan Tokoh Agama di Sintang, Ayah Long 56 tahun pada tanggal 05 Februari 2018.

59 Mahmud Arif, "Islam, Kearifan Lokal dan Kontekstualisasi Pendidikan: Kelenturan, Signifikansi, dan Implikasi Edukatifnya", dalam Jurnal Al-Tahrir, Vol. 15, No. 1, 2015, hlm. 86.

60 Wawancara dengan Tokoh Agama di Sintang, Ayah Long 56 tahun pada tanggal 05 Februari 2018. 


\section{Terempoh Keluarga}

Terempoh keluarga dilakukan di hari pertama lebaran tepatnya setelah salat Idul Fitri. Dalam terempoh keluarga ritual umum yang dilakukan masyarakat ialah ziarah kubur dan saling bermaaf-maafan atau sungkeman dalam istilah Jawa. Dalam tradisi terempoh keluarga ini, biasanya suka duka dan isak tangis akan terdengar dan diperlihatkan. Kegiatan terempoh keluarga dimulai dengan berkumpul di satu rumah anggota keluarga yang paling sepuh, atau biasa kita sebut nenek, kakek, moyang, datok, paman, atau bibik yang paling tua. Setelah semuanya nerempoh dalam satu rumah tersebut barulah sesi maaf-maafan dilakukan. Di salami satu persatu mulai dari yang tua hingga yang paling kecil dengan mengucapkan kalimat "Minta ampun, minta maaf bah," Nek, Kek, Tok, Man, Bik, dan sebagainya di ujung kalimat. ${ }^{61}$ Kalimat terakhir ini menyesuaikan dengan urutan saat kita bersalaman dengan masing-masing orang tersebut.

\section{Terempoh Laki-Laki}

Kegiatan ini dilakukan di hari kedua Idul Fitri dan menjadi puncak dari tradisi terempoh yang dilakukan. Kegiatan terempoh laki-laki dimulai dari pagi hingga sore selama satu hari, istirahat siang saat salat Zuhur, dan dilanjutkan kembali pukul 13.00 Wib hingga selesai. Kegiatan takbiran keliling dan terempoh keluarga ibarat pemanasan awal, namun yang menjadi hari puncaknya ialah hari kedua dan ketiga, yakni saat laki-laki terempoh dan para wanita menjalankan tugas dan perannya untuk menyiapkan menu terbaik tanpa menjadikan itu sebagai beban karena sudah menjadi kebiasaan dan rutinitas sehari-hari.

\section{Terempoh Perempuan}

Kegiatan ini dilakukan di hari ketiga. Kegiatan ini termasuk puncak dari tradisi terempoh, jadi acara puncak terempoh selama 2 hari yakni pada hari kedua dan ketiga. Menurut Ahmadin, saat terempoh perempuan berlangsung,

\footnotetext{
${ }^{61}$ Arti dari kalimat tersebut ialah 'dengan segala kerendahan hati dan jiwa saya minta maaf lahir batin' ke pada masing-masing orang yang ditujukan.
} 
maka giliran laki-laki yang menjadi kepala keluarga turun level menjadi bapak rumah tangga menggantikan sementara waktu posisi istri yang tanpa henti ada di ruang dapur untuk memastikan setiap perut anggota keluarganya aman ${ }^{62}$. Dalam tradisi ini terlihat bagaimana nilai persamaan dan gotong royong antara laki-laki dan perempuan dilakukan. Hal ini dapat dilihat melalui bagaimana dengan sangat bijak seorang laki-laki mengambil peran menggantikan peran perempuan dalam melayani keluarga dan tamu undangan. Hal ini juga merupakan tuntunan dari Rasulullah SAW sebagaimana hadits berikut:

Dari Al-Aswad, ia bertanya pada Aisyah, "Apa yang Nabi SAW lakukan ketika berada di tengah keluarganya?", Aisyah menjawab "Nabi SAW biasa membantu pekerjaan keluarganya di rumah. Jika telah tiba waktu shalat, beliau berdiri dan segera menuju shalat." (HR. Bukhari, No. 6039)

\section{Terempoh Kaum Kerabat}

Setelah terempoh laki-laki dan terempoh perempuan dilakukan, maka kegiatan terempoh dilanjutkan dengan terempoh kaum kerabat yang biasa dilakukan hingga berakhirnya bulan Syawal. Terempoh kaum kerabat ialah kegiatan silaturahmi yang diadakan secara bergiliran oleh anggota keluarga saja. Sebagai contoh, keluarga A mengunjungi keluarga B, lalu keluarga B pun membalas kunjungan dari keluarga A di hari berikutnya atau di hari yang sama di waktu yang berbeda. Kegiatan saling mengunjungi ini akan terus dilakukan hingga setiap keluarga telah habis dikunjungi baik kerabat yang tinggal di kawasan keraton Sintang maupun yang tinggal di luar wilayah tersebut. Gusti M. Padhil menjelaskan bahwa di era modern ini, kata terempoh bukan hanya dipakai dalam konteks antar keluarga dekat atau kaum kerabat saja, tetapi dengan keluarga jauh, bahkan tidak memiliki hubungan darah sekalipun, yang lebih unik lagi budaya ini sudah diadopsi oleh etnis dan umat beragama lainnya di Sintang. Dulunya milik masyarakat Melayu saja, namun kini sudah menjadi milik bersama63.

\footnotetext{
62 Wawancara dengan seorang guru Agama dan Imam Masjid, Ahmadin 50 tahun pada tanggal 02 Maret 2018.

${ }_{63}$ Fadli, Tradisi Terempoh......, hlm. 27.
} 


\section{Nilai-Nilai Multikultural dalam Tradisi Terempoh}

Allah SWT telah menciptakan manusia berbangsa-bangsa dan bersukusuku agar saling kenal mengenal, sebagaimana firman-Nya dalam QS. AlHujurat ayat 13 , sebagai berikut:

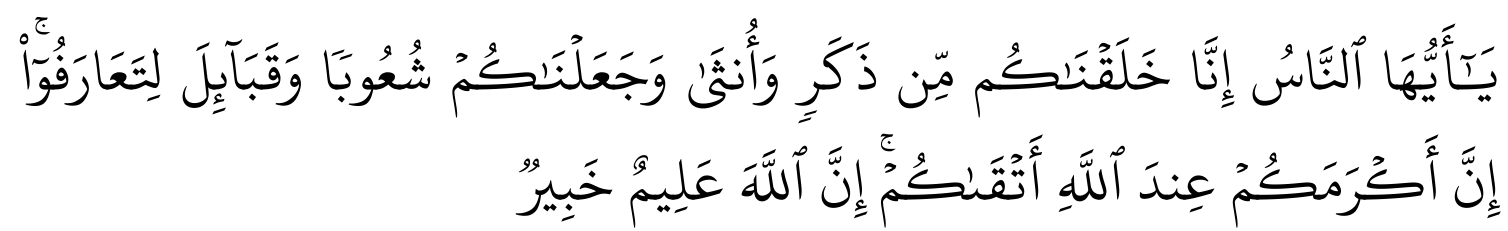

Artinya: "Hai manusia, sesungguhnya Kami menciptakan kamu dari seorang laki-laki dan seorang perempuan dan menjadikan kamu berbangsa-bangsa dan bersuku-suku supaya kamu saling kenal-mengenal. Sesungguhnya orang yang paling mulia di antara kamu di sisi Allah ialah orang yang paling bertaqwa di antara kamu. Sesungguhnya Allah Maha Mengetahui lagi Maha Mengenal ". (QS. Al-Hujurat: 13)

Perbedaan bangsa dan suku tersebut kita kenal dengan istilah multikultur. Multikultur yang hakiki, sejatinya dapat menerima perbedaan dan keberagaman tanpa memandang hubungan sosial, status sosial, hubungan kekerabatan, atau perbedaan antara suku, agama, dan etnis. Menurut Tilaar, Multikulturalisme adalah institusionalisasi dari keanekaragaman kebudayaan yang dimiliki oleh kelompok-kelompok etnis di dalam suatu nation-state melalui bidang-bidang atau sistem hukum, pendidikan, kebijakan pemerintah dalam kesehatan dan perumahan, bahasa, praktik-praktik keagamaan dan bidang lainnya ${ }^{64}$. Perbedaan yang merupakan fitrah tersebut harus dijaga bersama sebagaimana di katakan Azra, bahwa merawat kemajemukan, kebhinekaan, pluralisme dan atau multikulturalisme, harus dilakukan untuk merayakan kemajemukan di Indonesia, sebagai blessing in disguise bagi tahan air ini65. Berbagai suku di Indonesia memiliki peran dan fungsinya masingmasing, sebab bukan Indonesia jika satu tapi banyak yang menjadi satu kesatuan, “Bhineka Tunggal Ika”.

64 H.A.R. Tilaar, Multikulturalisme: Tantangan-tantangan Global Masa Depan dan Transformasi Pendidikan Nasional, (Jakarta: Grasindo 2004), hlm. 387.

65 Azyumardi Azra, Merawat Kemajemukan Indonesia: Seri Orasi Budaya, (Yogyakarta: Kanisius, 2007), hlm. 6. 
Tradisi terempoh di masyarakat Melayu Sintang dibangun atas keragaman ras, etnis, suku, dan agama, yang menjadikan tradisi ini terus eksis dan menjadi miniatur suatu adat istiadat yang kuat karena keanekaragamannya. Hal ini dapat dilihat dari bagaimana tradisi ini dapat menerima semua suku, agama, dan etnis apapun untuk ikut terlibat dalam tradisi terempoh, yang sejatinya tanpa ada ikatannya apapun dalam masyarakat ${ }^{66}$. Dengan demikian semakin jelas bahwa terdapat nilai-nilai multikultural dalam pelaksanaan tradisi terempoh.

Berdasarkan hasil penelitian diketahui bahwa tradisi terempoh memiliki nilai-nilai luhur dan dimaknai bersama sebagai simbol kekerabatan dan alat silaturahmi yang dipercaya oleh masyarakat Melayu Sintang. Adapun nilainilai multikultural yang terdapat dalam tradisi terempoh masyarakat Melayu Sintang, yaitu:

\section{Nilai Keberagaman}

Keberagaman merupakan salah satu nilai multikultural yang tampak dalam tradisi terempoh. Tradisi ini diikuti oleh seluruh masyarakat "Melayu" Sintang yang memiliki perbedaan suku, agama, bahkan etnis. Pelaksanaan tradisi terempoh tidak memilah dan memilih siapa saja yang terlibat didalamnya, namun semua warga masyarakat ikut serta sebagai ajang untuk mempererat tali persaudaraan diantara mereka. Tradisi terempoh dapat menyatukan seluruh elemen masyarakat. Uniknya lagi, selain melaksanakan silaturahmi secara serempak (bersama-sama), kita mampu menikmati hidangan-hidangan yang beraneka ragam tanpa melewati satu rumah warga yang ikut serta. ${ }^{67}$.

Toni menambahkan, tradisi ini bisa membuat masyarakat berkumpul dengan sangat ramai seperti diberi komando. Makanan bervariasi dan beranekaragam, mulai dari makanan khas-khas Melayu, Kalimantan Barat

\footnotetext{
${ }^{66}$ Wawancara dengan Pemerhati Seni Kabupaten Sintang, Syamsul Bachri pada tanggal 05 Februari 2018.

${ }^{67}$ Wawancara dengan Aktifis Sosial dan Dharma Wanita, Syafariyah 37 tahun pada tangal 03 Februari 2018.
} 
hingga makanan-makanan Jawa. Begitu pula kue dan makanan ringan lain yang sudah tidak perlu ditanyakan lagi keanekaragamannya68. Ahmadin menambahkan, dulu suku Dayak banyak yang mengikuti kegiatan terempoh ini. Semua warga, tokoh masyarakat, tokoh agama, anak muda, orang tua sampai manula bahkan orang-orang Dayak atau nonmuslim pernah mengikuti tradisi tersebut sekitar tahun $80-$ an $^{69}$.

\section{Nilai Kesetaraan}

Pada awalnya terempoh hanya dilakukan oleh laki-laki sementara perempuan menunggu di rumah sambil menyiapkan hidangan untuk para tamu, namun seiring dengan waktu dan perkembangan zaman, serta perjuangan tokoh pahlawan wanita tentang emansipasi, maka berkembang pula tradisi terempoh bagi perempuan dan tetap eksis serta diterima oleh masyarakat hingga saat ini ${ }^{70}$. Hal ini menunjukkan ketidaksetaraan antara lakilaki dan perempuan pada masa itu. Namun seiring perjalanan waktu dan perjuangan tokoh wanita melayu, maka keikut sertaan wanita pun semakin terlihat dan diterima di masyarakat. Adapun nilai multikultural yang terkandung dalam nilai kesetaraan, yaitu: membangun saling percaya, memelihara saling pengertian, dan menjunjung sikap saling menghormati.

\section{Nilai Kemanusiaan}

Data di lapangan menunjukkan bahwa nilai kemanusian dalam tradisi ini terlihat dari bagaimana dulunya tradisi terempoh digunakan sebagai alat informasi dan komunikasi untuk mengetahui keadaan sosial setiap warga. Sebagaimana dikatakan Ahmadi bahwa terempoh digunakan untuk saling berbagi dan untuk mengetahui keadaan hidup tetangga ${ }^{71}$. Dari kegiatan terempoh inilah dilakukan musyawarah dan mufakat untuk menindak lanjuti

\footnotetext{
68 Wawancara dengan PNS BKD, Toni 41 tahun pada tanggal 02 Maret 2018.

${ }^{69}$ Wawancara dengan guru Agama dan Imam Masjid, Ahmadin 50 tahun pada tanggal 02 Maret 2018.

70 Wawancara dengan pencetus lahirnya terempoh perempuan, Halimatussa'diyah 61 tahun pada tanggal 02 Maret 2018.

${ }^{71}$ Wawancara dengan guru Agama dan Imam Masjid, Ahmadin 50 tahun pada tanggal 02 Maret 2018.
} 
keadaan saudara, tetangga, atau kaum kerabat kita yang sedang dalam kondisi yang membutuhkan bantuan.

\section{Nilai Keadilan}

Nilai selanjutnya ialah nilai keadilan, sebenarnya ini juga termasuk ke dalam nilai-nilai kemanusiaan dan nilai-nilai Islam, yang sifatnya mendasar yang dibawa oleh Islam yang dijadikan sebagai pilar kehidupan baik secara pribadi, keluarga, dan masyarakat. Di dalam tradisi terempoh sendiri wujud dari berlaku adil ialah tidak membeda-bedakan suku, agama, dan etnis, tidak memilih antara orang kaya dan miskin. Setiap masyarakat yang berada di lingkungan tradisi yang kita lakukan maka mereka memiliki kewajiban yang sama untuk mengikuti tradisi tersebut dan dalam pelaksanaannya, setiap dari kita wajib memberikan hak dan perlakuan yang sama kepada tamu tanpa membeda-bedakannya.

Dalam tradisi terempoh juga menerapkan sanksi sosial sebagaimana dikatakan Ayah Long ketika ditanya tentang adanya sanksi bagi yang tidak ikut serta dalam terempoh. "Iya mendapatkan sanksi dikucilkan oleh masyarakat itu sudah jelas. Tapi sanksinya sesuai kesepakatan, barangsiapa yang rumahnya mau dinaiki dia harus ikut terempoh. Jika tidak ikut, kita tidak akan menaiki rumahnya lagi, biar ada efek jera"72.

\section{Nilai Toleransi}

Menurut peneliti sebenarnya nilai yang utama ialah nilai toleransi. Kita sering terperangkap mengartikan "toleransi antar umat beragama", yang diartikan dengan mencampuradukkan ritual keagamaan. Bila kaum Nasrani natalan, kita dianjurkan mengikutinya dengan datang kepada mereka. Padahal sikap ini bukan malah menunjukkan sikap toleransi, malah menunjukkan sikap kemunafikan dalam diri sendiri. Jadi, saat berinteraksi dengan non-muslim, prinsip toleransi, keadilan, dan kebenaran harus kita tegakkan, sementara untuk urusan akidah, kita harus tetap pada keyakinan kita dan teguh

\footnotetext{
72 Wawancara dengan Tokoh Agama di Sintang, Ayah Long 56 tahun pada tanggal 05 Februari 2018.
} 
memegang pendiriannya. Dalam tradisi terempoh, keikutsertaan orang-orang di dalam pelaksanaannya bukanlah suatu bentuk ajakan atau menyuruh mengikuti agama Islam, namun lebih tepat adalah mengajak non-muslim untuk membiasakan perilaku toleransi dalam kehidupan sehari-hari.

\section{Nilai Demokratis}

Salah satu wujud dari nilai demokratis dari tradisi terempoh dapat ditemukan pada prosesi shalat berjamaah di malam terakhir bulan Ramadhan. Seperti mendapat perintah, kaum lelaki sepakat pergi ke masjid untuk shalat berjamaah sekaligus melakukan musyawarah tahunan untuk menunggu keputusan apakah besok akan dilakukan shalat Idul Fitri atau tidak. Musyawarah dilakukan dengan menentukan dimana akan memulai terempoh yang setiap tahun akan berganti startnya. Agama Islam menjadikan musyawarah sebagai aturan meneliti dan menelaah pendapat-pendapat untuk mengambil jalan tengah, yaitu bijak memilih pendapat sesuai dengan kesepakatan bersama. Islam juga memberikan kebebasan berpendapat bagi setiap orang selama pendapatnya tidak bertentangan dengan Al-Qur'an dan Hadits. Oleh karena itu, seseorang yang memiliki sifat suka bermusyawarah, artinya dia telah menunjukkan sikap demokratis.

\section{E. Nilai-Nilai Pendidikan Islam dalam Tradisi Terempoh}

Pengertian pendidikan Islam mengacu pada 3 kata, yakni: tarbiyah, ta'lim, dan $t a^{\prime} d i b$. Dari ketiga kata tersebut, kata tarbiyah lebih sering digunakan yang memiliki arti yaitu proses transformasi ilmu pengetahuan dari pendidik kepada peserta didik agar memiliki sikap dan semangat yang tinggi dalam memahami dan menyadari kehidupannya, sehingga terbentuk ketakwaan, budi pekerti, dan kepribadian yang luhur73. Adapun proses pendidikan Islam yang ditujukan Nabi merupakan bentuk pelaksanaan pendidikan yang bersifat fleksibel dan universal, sesuai dengan potensi yang dimiliki manusia, kebiasaan masyarakat, serta kondisi alam dimana proses pendidikan tersebut

\footnotetext{
${ }^{73}$ Abdul Mujib dan Jusuf M., Ilmu Pendidikan Islam, (Jakarta: Kencana, 2006), hlm. 13.
} 
berlangsung 74 . Terempoh adalah suatu tradisi yang sudah menjadi kebudayaan yang bernafaskan Islam, yang lahir sejak Islam tumbuh pesat dan berkembang di Sintang. Dalam kegiatan ini terkandung nilai-nilai budaya yang positif, seperti : silaturahmi, saling memaafkan, menghormati tamu, dan lain-lain75. Syafariyah menjelaskan bahwa nilai-nilai yang terkandung di dalam tradisi terempoh sangat banyak, seperti: Nilai religi, yaitu menghargai setiap orang tanpa memilih tua dan muda, kaya atau miskin; Nilai akhlak, yaitu menghargai setiap pemberian atau hidangan dengan ikhlas. Dari segi sosial, kita dapat berbaur dengan masyarakat di sekitar lingkungan kita, sebab itu mebuktikan bahwa kita adalah makhluk sosial yang tidak bisa hidup tanpa bantuan orang lain ${ }^{76}$. Adapun nilai pendidikan Islam yang ditemukan dalam penelitian ini, yaitu:

\section{Nilai Religius}

Jika dari ranah kebudayaan tradisi terempoh dimaknai sebagai kesempatan untuk menjalin silaturahmi, maka dari ruang lingkup religi, tradisi terempoh memiliki nilai-nilai Islam, sehingga momentum terempoh sebagai tuntunan suatu agama yang merupakan bagian dari ritual sekaligus sebagai sarana melestarikan kearifan lokal. Adapun sifat-sifat yang akan muncul dari tradisi terempoh ialah:

Pertama, kerendahan hati. Tradisi terempoh dilakukan untuk menyatukan seluruh lapisan masyarakat tanpa pandang bulu, yakni menyingkirkan sikap sombong dan ego dari diri sendiri. Bahkan yang kurang bergaul dalam lingkungan masyarakat karena kesibukan dan berbagai tuntutan, menurunkan rasa egonya yang besar karena silaturahmi dalam tradisi ini adalah silaturhami masal sehingga mau tidak mau dia akan ikut terlibat dalam tradisi ini.

\footnotetext{
74 Samsul Nizar, Pengantar Dasar-Dasar Pemikiran Pendidikan Islam, (Jakarta: Gaya Media Pratama, 2001), hlm. 97.

75 Wawancara dengan pencetus lahirnya terempoh perempuan, Halimatussa'diyah 61 tahun pada tanggal 03 Februari 2018.

76 Wawancara dengan Aktifis Sosial dan Dharma Wanita, Syafariyah 37 tahun pada tanggal 03 Februari 2018.
} 
Kedua, sifat pemaaf. Inti dari tradisi terempoh itu sendiri sebenarnya memang sebagai ajang untuk saling memaafkan satu dengan yang lain. Dalam tradisi terempoh ada kebiasaan membacakan doa dan sebelum memasuki rumah seseorang harus mengucapkan salam dan bersalam-salaman sambil mengucapkan permohonan maaf "maaf lahir batin bah...!" kurang lebih seperti itu bunyi kalimatnya. Jika acara halal bi halal hanya memeriahkan acara lebaran dengan berkumpul bersama keluarga dan makan-makan. Maka pada tradisi terempoh segala kesalahan masa lalu diikhlaskan untuk saling memafkan.

\section{Nilai Kasih Sayang}

Di dalam tradisi terempoh ini juga memiliki nilai kasih sayang yang sangat kental. Hal ini terlihat dari prosesi trempoh yang tidak membedabedakan dan saling kasih mengasihi antar sesama. Jika berbicara kasih sayang ini juga termasuk akhlak Rasulullah saw. Kasih sayang Beliau tidak terbatas, baik kepada muslim atau nonmuslim, kawan atau lawan, yang merdeka atau budak, orang tua atau muda, besar atau kecil, bahkan pada binatang dan tumbuhan. Betapa mulianya akhlak Rasulullah yang hingga hari ini menjadi suri tauladan bagi seluruh umatnya.

\section{Nilai Kesantunan}

\section{a. Membudayakan Salam}

Prosesi pertama dalam tradisi terempoh ialah mengucapkan salam terlebih dahulu. Tidak ada satu rumah pun yang terlewatkan dengan tanpa mengucapkan salam terlebih dahulu dan setiap tamu kemudian bersalaman (jabat tangan) dengan tuan rumah. Adab dalam Islam memang indah karena jika kita pikir secara logika, untuk apa mengucapkan salam di setiap rumah padahal tuan rumah memang sudah menunggu giliran rumahnya untuk dinaiki atau di terempoh. Dengan adanya tradisi ini, generasi muda belajar menghormati orang yang lebih tua, lebih muda dan yang seusia dengannya.

Imam an-Nawawi berkata, "Adapun jika seseorang mendatangi beberapa orang yang sedang duduk-duduk atau duduk sendiri, maka hendaklah orang yang datang 
memulai salam terlebih dahulu kepada setiap orang yang didatanginya, baik ia seorang anak yang masih kecil atau sudah dewasa, sedikit maupun banyak." (H.R Ahmad 1/407-408)

\section{b. Memuliakan Tamu}

Tradisi terempoh memberikan pelajaran bahwa sejatinya seseorang yang taat beragama dan serius dalam mengarungi jalan keimanan, akan dengan senang hati menyambut, menghormati, dan memuliakan tamu-tamu yang datang ke rumahnya. Selain menunjukkan kemuliaan kita, di dalamnya juga melatih seseorang individu bersifat tawakkal dan rendah hati, di dalam memuliakan tamu juga banyak hal yang dikorbankan. Mulai dari tenaga, waktu dan finansial, maka dari itu di dalam tradisi ini juga ada yang namanya nilai ketulusan dan keikhlasan.

\section{Nilai Kepedulian Sosial}

Jika dilihat dari segi sosiologis, tradisi terempoh ini memang sangat efektif untuk memperkuat ikatan persaudaraan serta hubungan sosial. Dalam banyak hal untuk urusan kepedulian sosial, yang menjadi teladan kita yaitu Rasulullah saw. Segala akhlak yang baik semua menjadi bagian dari kehidupan kekasih Allah ini dalam kehidupan sehari-hari beliau. Hal ini senada dengan ungkapan dari salah satu masyarakat pendatang yang mengikuti tradisi terempoh. Di dalam tradisi terempoh ukhkuwah atau persaudaraan terpancar dari setiap proses di dalam tradisi ini. Jika dilihat dari urutan demi urutannya tidak ada yang tidak mengandung unsur ukhkuwah. Bahkan selain persaudaraan ada nilai kerjasama dan gotong royong di dalamnya.

\section{F. Kesimpulan}

Tradisi terempoh masyarakat Melayu Sintang memiliki nilai multikultural dan nilai pendidikan Islam di dalam pelaksanaanya. Pelaksanaan tradisi terempoh pada masyarakat Melayu Sintang dilakukan melalui: Pertama, Takbiran keliling; Kedua, Terempoh keluarga; Ketiga, Terempoh laki-laki; Keempat, Terempoh perempuan; dan Kelima, Terempoh kaum kerabat. 
Adapun nilai-nilai multikultural yang terdapat dalam tradisi terempoh ialah:

Pertama, Keberagaman, seperti: menerima perbedaan suku, agama, dan etnis, hidup dalam perbedaan, dan menghargai perbedaan pendapat; Kedua, Kesetaraan, seperti: persamaan gender, dan menghargai yang lebih tua, memelihara saling percaya serta memelihara saling pengertian; Ketiga, Kemanusiaan, seperti: sarana komunikasi untuk mengetahui orang-orang yang membutuhkan, saling berbagi, dan menaruh rasa saling peduli; Keempat, Keadilan, seperti: memberi hak sesuai dengan yang membutuhkan, tidak membeda-bedakan suku, agama dan ras, serta tidak memilih kaya dan miskin; Kelima, Toleransi, seperti: memahami eksistensi agama orang lain dan bersikap toleran dalam lingkungan masyarakat; dan Keenam, Nilai Demokrasi, seperti: musyawarah atau mendiskusikan segala sesuatu untuk mencapai mufakat.

Sedangkan nilai-nilai pendidikan Islam yang terdapat dalam tradisi terempoh ialah: Pertama, Religius, seperti: kerendahan hati (tawadhu'), ikhlas dalam bersikap, dan menjadi pribadi yang pemaaf dalam masyarakat; Kedua, Kasih Sayang, seperti: membangun kedekatan dengan keluarga dan tetangga, saling menyayangi dan bersikap lemah lembut; Ketiga, Kesantunan, seperti: membudayakan mengucapkan salam, dan menjawabnya, serta bersalaman saat bertemu dengan saudara seiman. Selain itu juga memuliakan tamu sebagaimana mestinya; dan Keempat, Kepedulian sosial, seperti: bergaul dengan baik di lingkungan sekitar, saling tolong menolong antar sesama, dan saling berbagi dan peduli.

\section{DAFTAR PUSTAKA}

Arif, Mahmud, "Islam, Kearifan Lokal dan Kontekstualisasi Pendidikan:

Kelenturan, Signifikansi, dan Implikasi Edukatifnya", Jurnal Al-Tahrir, Vol. 15, No. 1, 2015.

Azra, Azyumardi, Merawat Kemajemukan Indonesia: Seri Orasi Budaya, Yogyakarta: Kanisius, 2007. 
Badan Pusat Statistik Kacamatan Sintang, Kecamatan Sintang Dalam Angka 2014, Sintang: BPS, 2017.

Fadli, Gusti Muhammad, Tradisi Terempoh dalam Era Modernisasi: Kajian Tradisi Masyarakat Melayu Sintang-Kalimantan Barat, Sintang: Sultan Nata, 2017.

Halimatussa'diah, “Budaya Terempoh pada Masyarakat Rt 06/ Rw 02 Kelurahan Kapuas Kiri Hulu Sintang dalam Perspektif Pendidikan Islam", Skripsi tidak diterbitkan, Pontianak: IAIN Pontianak, 2005.

Koentjaraningrat, Pengantar Ilmu Antropologi, Jakarta: Aksara Baru, 1985.

Kurniawan, Syamsul, "Serapah dalam Masyarakat Melayu Kampung Saigon Kota Pontianak", Jurnal Religi, Vol. IX, No. 1, 2013.

Liliweri, Alo, Pengantar Studi Kebudayaan, Bandung: Nusa Media, 2014.

Milles, Metthew B. dan A. Michael Huberman, Analisis Data Kualitatif: Buku Sumber tentang Metode-Metode Baru, Penerjemah: Tjetjep Rohendi Rohidi, Jakarta: UI-Press, 2014.

Moleong, Lexy J., Metodologi Penelitian Kualitatif, Bandung: Remaja Rosdakarya, 2007.

Mujib, Abdul dan Jusuf Mudzakkir, Ilmu Pendidikan Islam, Jakarta: Kencana, 2006.

Nizar, Samsul, Pengantar Dasar-Dasar Pemikiran Pendidikan Islam, Jakarta: Gaya Media Pratama, 2001.

Tilaar, H.A.R., Multikulturalisme: Tantangan-tantangan Global Masa Depan dan Transformasi Pendidikan Nasional, Jakarta: Grasindo, 2004. 